\title{
WAIST CIRCUMFERENCE CUT-OFF POINTS OR BODY MASS INDEX FOR PREDICTING FAT MASS IN COLLEGE STUDENTS
}

\author{
Bayner Julian RAMIREZ-CALDERON ${ }^{1}$ \\ Clara Helena GONZALEZ-CORREA ${ }^{2}$ \\ Carlos Augusto GONZALEZ-CORREA ${ }^{3}$
}

- ABSTRACT: Obesity affects millions of people worldwide, becoming a public health problem with serious implications for human life quality. This is why low-cost prevention and diagnostic strategies that are accessible to the entire population are needed. Low-cost and easy-to-use strategies include the measurement of Body Mass Index (BMI) and measurement of waist circumference (WC). The objective was to determine whether the percentage of body fat in Colombian college students can be predicted through BMI or WC, establishing WC cutoff points. This was a descriptive cross-sectional study with a simple random sample. The study included 687 students aged 18-35 years old from both sexes. Anthropometric measures of weight, length, waist circumference at navel level and skin folds (bicipital, tricipital, subscapular and suprailiac) were obtained. The sensitivity and specificity of BMI and the waist circumference at navel level (WCN) were determined to predict the estimated percentage of body fat by measuring skin folds. The cutting points of the waist circumference for men and women were determined by drawing up a Receiver Operating Characteristic Curve (ROC). Greater sensitivity and specificity of WCN were found in comparison with BMI, to predict the percentage of body fat.

- KEYWORDS: Obesity; body mass index (BMI); waist circumference (WC); thickness of skin folds.

\section{Introduction}

Obesity is defined as the excess of body fat (KAVAK et al., 2014). The interest in its study and physiopathology has increased over the last few years, given the physical and psychosocial implications and its impact on people's health. According to data from the latest National Survey of Nutritional Situation in Colombia (ENSIN, 2010), one out of two adults is overweight and one out of six is obese (FONSECA-CENTENO, 2011). Obesity is linked to cardiovascular complications and the development of diabetes

\footnotetext{
${ }^{1}$ Universidad de Caldas, Faculty of Health Sciences, Research Group on Electrical Bioimpedance, Postal Code: 170004 Manizales, Caldas, Colombia. E-mail: bayner.521121435@ucaldas.edu.co

${ }^{2}$ Universidad de Caldas, Department of Basic Health Sciences. Faculty of Health Sciences, Research Group on Nutrition, Metabolism and Food Security, Postal Code: 170004, Manizales, Caldas, Colombia. E-mail: clara.gonzalez@ucaldas.edu.co

${ }^{3}$ Universidad de Caldas, Department of Basic Health Sciences. Faculty of Health Sciences, Research Group on Electrical Bioimpedance, Postal Code: 170004, Manizales, Caldas, Colombia. E-mail: c.gonzalez@ucaldas.edu.co
} 
Mellitus type 2, among other diseases (ROMAIN et al., 2012). Furthermore, the abdominal fat gain is associated with increased risk in the mentioned circumstances. This increase can be determined by measuring the WC (WALL-MEDRANO et al., 2016).

The BMI and the WC measurement are the two most commonly used anthropometric tools for determining overweight and obesity in adults, due to their simplicity in implementation and low cost, favoring their use in daily clinical practice (RAMIREZVELEZ et al., 2017). While BMI is used to assess thinness and obesity, its usefulness is limited since it does not determine the fat mass and its distribution in the body (NUTTALL, 2015). On the other hand, an increase in WC reflects an increase in the amount of intra-abdominal fat including visceral adipose tissue. A correlation has been reported between the increase in visceral fat tissue and the risk of cardiovascular disease (GONZÁLEZ-MUNIESA et al., 2017) and the development of certain cancers (OTTAIANO et al., 2018). Waist circumference values have been established by the International Diabetes Federation as a diagnostic criterion for metabolic complications (HU et al., 2016; ALBERTI et al., 2005).

This study aims to determine whether the percentage of body fat in Colombian college students can be predicted through BMI or WC.

\section{Materials and methods}

\subsection{Subjects}

This is a cross-sectional descriptive study, carried out in the city of Manizales (Colombia) from 1995 to 2013, in a population of male and female Colombian college students from the Universidad de Caldas, aged between 18 and 35 years. The population was recruited through announcements, published in leaflets and on the University's website. The study was carried out following the guidelines of the Helsinki Declaration. The project was approved by the Ethics Committee of the Health Faculty. Participants, after signing informed consent, were surveyed to obtain data of socio-demographic importance: age, gender, curriculum, identification document and city of origin. All participants were provided with comprehensive verbal explanations about the nature, objectives and experimental risks of the study. Pregnant women, not university students, people with walking impairments, a clinical or medical diagnosis of diseases such as hypothyroidism, hyperthyroidism, type 1 and 2 diabetes, malnutrition, drug or alcohol abuse history, chronic inflammatory conditions such as systemic lupus erythematosus, rheumatoid arthritis, and people who were taking medications that affected body composition, such as multivitamins or steroids were excluded. The information was obtained by self-report and the medical history of the participants. 


\subsection{Methods}

Measurements were made at the University's nutritional assessment laboratory. The participants removed their shoes and wore only their underwear and a hospital gown. The waist circumference was measured at the navel level (WCN) using a measuring tape, with accuracy of $\pm 1 \mathrm{~mm}$ and without skin compression. The height measurement was performed with the subject standing, using a Heightronic 235 digital stadiometer from Seca Corp., with an accuracy of $\pm 0.5 \mathrm{~cm}$. The weight was established using the IconDetecto PP 2000 digital scale, with an accuracy of $\pm 0.1 \mathrm{~kg}$. The BMI was calculated as the weight $(\mathrm{kg})$ divided by height, in square meters $(\mathrm{m} 2)$. Skin folds were measured at the bicipital, tricipital, subscapular and suprailiac levels with a Skyndex $\mathrm{II}^{\circledR}$ digital plicometer, according to the method described by Lohman et al., (1992). The fat percentage was estimated according to the formula of Durnin and Womersley, which is included in the plicometer software (DURNIN and WOMERSLEY, 1974). Obesity was defined from a percentage of body fat $>30 \%$ in women and $>25 \%$ in men (YANG et al., 2006). For the analysis of the results, SPSS version 15, a license on behalf of the Universidad de Caldas, was used. The sensitivity and specificity of BMI and WCN were calculated for predicting body fat percentage using the ROC curves. These curves evaluate the accuracy of a diagnostic test and its potential to establish the presence or absence of a condition that interferes with the health of individuals (KAVAK et al., 2014).

\section{Results}

The characteristics of the subjects are presented in Table 1. The values of the area under the ROC curve for the cut-off points of sensitivity and specificity are presented in Table 2. Both BMI and WCN showed predictive ability to identify individuals with increased adiposity in both genders, compared to the percentage of body fat. The areas below the curve of both indicators for men and women are shown in Figures 1 and 2, respectively. Confidence intervals are present in tables 2 and 3. The area under the BMI curve was smaller than WCN in both sexes $(\mathrm{p}<0.05)$. Furthermore, the data obtained from the ROC curves allowed determining cut-off points of WC for this population (Table 4). 


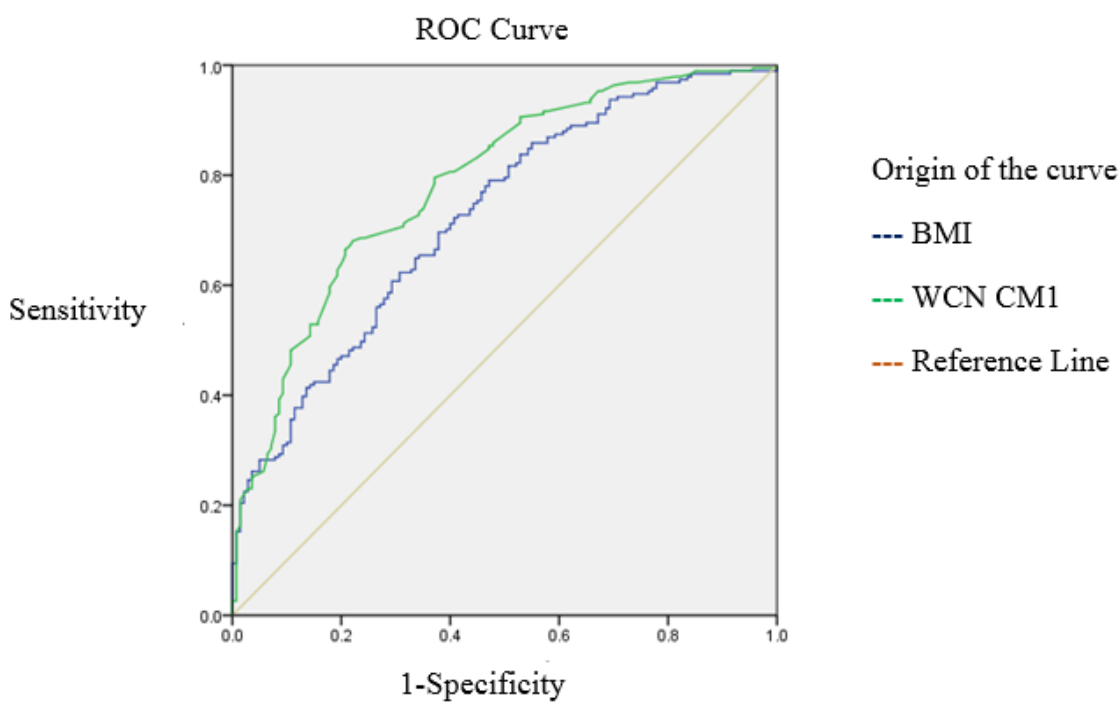

Figure 1 - Area under the ROC curve of anthropometric indicators when predicting the percentage of fat in men.

Table 1 - Characteristics of the population studied (n=687)-Manizales, 1995-2013, BMI, Body Mass Index, WCN, Waist Circumference at Navel level, SD, Standard Deviation

\begin{tabular}{lrrrr}
\hline & \multicolumn{2}{c}{ Men $(\mathrm{n}=331)$} & \multicolumn{2}{c}{ Women $(\mathrm{n}=356)$} \\
& $\mathrm{M}$ & $\mathrm{SD}$ & \multicolumn{1}{c}{$\mathrm{M}$} & $\mathrm{SD}$ \\
\hline Body mass $(\mathrm{kg})$ & 62.3 & $(9.0)$ & 54.9 & $(8.0)$ \\
Height $(\mathrm{m})$ & 1.7 & $(0.1)$ & 1.6 & $(0.1)$ \\
BMI $\left(\mathrm{kg} / \mathrm{m}^{2}\right)$ & 21.7 & $(2.7)$ & 22.2 & $(3.1)$ \\
WCN $(\mathrm{cm})$ & 77.3 & $(7.1)$ & 74.6 & $(11.1)$ \\
Bicipital fold $(\mathrm{mm})$ & 8.1 & $(5.4)$ & 12.7 & $(5.1)$ \\
Tricipital fold $(\mathrm{mm})$ & 13.5 & $(6.2)$ & 20.3 & $(6.3)$ \\
Subscapular fold $(\mathrm{mm})$ & 16.8 & $(6.9)$ & 22.2 & $(8.7)$ \\
Suprailiac fold $(\mathrm{mm})$ & 23.6 & $(11.0)$ & 28.3 & $(10.8)$ \\
Total folds & 62.1 & $(26.4)$ & 83.6 & $(28.4)$ \\
Age (years) & 22.8 & $(3.9)$ & 21.7 & $(2.9)$ \\
Fat $(\%)$ & 20.6 & $(5.6)$ & 32.9 & $(5.3)$ \\
\hline
\end{tabular}


Table 2 - Confidence intervals in men Area under the curve

\begin{tabular}{|c|c|c|c|c|c|}
\hline \multirow{2}{*}{$\begin{array}{l}\text { Variants } \\
\text { of test } \\
\text { results }\end{array}$} & \multirow[t]{2}{*}{ AUC } & \multirow[t]{2}{*}{$\begin{array}{l}\text { Standard } \\
\text { error a }\end{array}$} & \multirow[t]{2}{*}{$\begin{array}{c}\text { Asymptotic } \\
\text { significance }\end{array}$} & \multicolumn{2}{|c|}{$\begin{array}{c}\text { 95\% of asymptotic confidence } \\
\text { interval }\end{array}$} \\
\hline & & & & Lower limit & Upper limi \\
\hline BMI & 0.725 & 0.028 & 000 & 0.671 & 0.779 \\
\hline WCN & 0.786 & 0.025 & 000 & 0.737 & 0.836 \\
\hline
\end{tabular}

AUC: Area under the Curve. BMI: Body Mass Index. WCN: Waist Circumference at Navel level

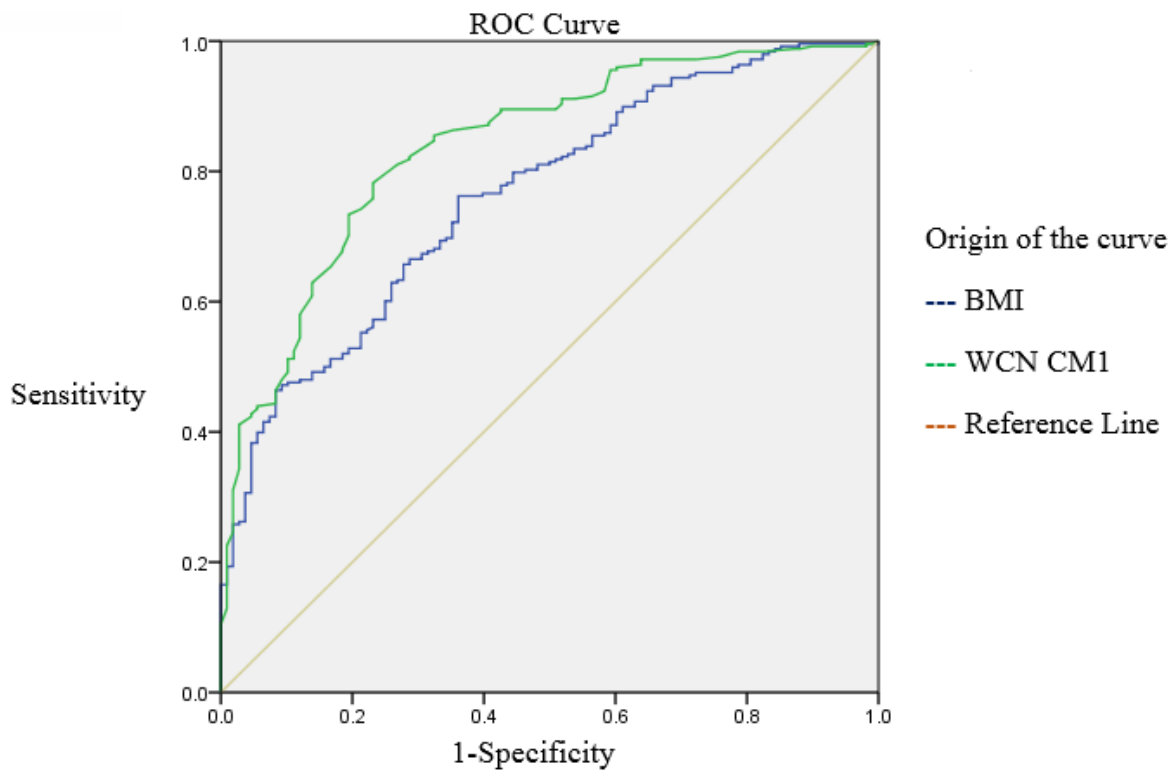

Figure 2 - Area under the ROC curve of anthropometric indicators when predicting the percentage of fat in women.

Table 3 - Confidence intervals in women. Area under the curve

\begin{tabular}{lcc}
\hline Index & Men & WCN \\
& & Women \\
\hline WCN & 0.786 & 0.838 \\
Cut off point $(\mathrm{cm})$ & 70 & 64 \\
Sensitivity & $97 \%$ & $97 \%$ \\
Specificity & $81 \%$ & $70 \%$ \\
\hline
\end{tabular}

AUC: Area under the curve. BMI: Body mass index. WCN: Waist circumference at navel level 
Table 4 - WCN cut-off points for predicting excess body fat in both sexes

\begin{tabular}{|c|c|c|c|c|c|}
\hline \multirow[t]{2}{*}{$\begin{array}{l}\text { Variants of } \\
\text { test results }\end{array}$} & \multirow[t]{2}{*}{ AUC } & \multirow[t]{2}{*}{$\begin{array}{c}\text { Standard } \\
\text { error }^{\text {a }}\end{array}$} & \multirow[t]{2}{*}{$\begin{array}{l}\text { Asymptotic } \\
\text { significance }^{\text {b }}\end{array}$} & \multicolumn{2}{|c|}{$\begin{array}{l}\text { 95\% of asymptotic confidence } \\
\text { interval }\end{array}$} \\
\hline & & & & Lower limit & Upper limit \\
\hline BMI & 0.763 & 0.026 & 000 & 0.711 & 0.814 \\
\hline WCN & 0.838 & 0.022 & 000 & 0.794 & 0.882 \\
\hline
\end{tabular}

AUC: Area under the curve. WCN: Waist circumference at navel level

\section{Discussion}

The high global prevalence of obesity and the associated metabolic syndrome has led the International Diabetes Federation (IDF) to develop guidelines for its diagnosis and treatment. Among the recommendations, the measurement of waist circumference has been proposed as a simple, low-cost parameter for estimating abdominal obesity.

Visceral fat surrounds the abdominal organs that have endocrine activity. These organs release fatty acids into the bloodstream. Those acids promote the production of very-low-density lipoproteins (VLDL) and low-density cholesterol (LDL-c). These cholesterol levels promote the formation of atherosclerotic plaques, increasing cardiovascular risk. Fatty tissue also promotes the formation of pro-inflammatory cytokines 1 and 6 , as well as the release of tumour necrosis factor Alpha. Visceral fat also stimulates the formation of reactive $\mathrm{C}$ protein and is an activating factor of plasminogen type 1 (PAI 1) in the liver, contributing to the generation of inflammatory and prothrombotic processes (STANLEY and GRINSPOON, 2015). Given these phenomena, measurement of the waist circumference can determine the risk of cardiovascular disease and metabolic syndrome (MACIAS et al., 2014).

The literature reports different anatomical points for the measurement of waist circumference. The most referenced sites in the literature are the navel $(28 \%)$ and the midpoint between the last rib and the iliac crest (29\%). The remaining percentage is divided among the other anatomical sites (KLEIN et al., 2007). In a systematic review of 120 studies, eight protocols were reported for the measurement of waist circumference (ROSS et al., 2008). Studies comparing different protocols have reported that absolute waist circumference measurement values vary, depending on the anatomical site being evaluated (SHARIATPANAHI and VAHDAT, 2016). These discrepancies cause the cutoff points obtained to change between protocols. Thus, it is necessary to call for a global consensus to establish an anatomical point and a defined protocol. In this way, the real differences that exist by gender and between different populations can be demonstrated (RAMIREZ-VELEZ et al., 2016).

In Latin America, there are few studies on this subject and there are no defined cut-off points as a reference for the measurement of the waist circumference. Despite this, the IDF recommends using Asian population cuts: $90 \mathrm{~cm}$ for men and $80 \mathrm{~cm}$ for women (ALBERTI et al., 2005; HERNANDEZ et al., 2013). Anthropometric similarities seem to exist between the Asian population and the Latin American community (BUENDÍA et al., 2016). However, South America has particular characteristics because its population is the product of mixing between Europeans, Amerindians, and Africans. Besides, the cut-off 
points of both BMI and WC are influenced by gender and age (RAO et al., 2015). These factors create the need to establish our cut-off points for a population rich in ethnic and cultural diversity (RIVERA et al., 2014).

Buendia et al. (2016) carried out a study with 501 Colombian subjects, taking as anatomical points the one used for the Asian population. The values found by them (91 $\mathrm{cm}$ in men and $89 \mathrm{~cm}$ in women) are close to those reported for Asian men but not for women, with which there would be a difference of $9 \mathrm{~cm}$.

Another study in Colombia, with the participation of 83.220 subjects, used the same anatomical site of Buendia. Cutting points of $96.6 \mathrm{~cm}$ were found for men and $91.0 \mathrm{~cm}$ for women (RAMIREZ-VELEZ et al., 2016). The difference could be explained by the diverse sample sizes and differences within the same Colombian population, where there is ethnic diversity by region.

A third study, with a Colombian population of 800 subjects, used the HOMA (Homeostasis Model Assessment of Insulin Resistance) as the reference method. The anatomical site used was the narrowest area between the rib cage border and the iliac crest. The authors reported different values: $92 \mathrm{~cm}$ for men and $84 \mathrm{~cm}$ for women. In this case, the difference in the points could be partly explained by the reference method used and the characteristics of the sample (ALEMAN-MATEO et al., 2014).

In the present study, the cut-off points found (both for men and women) are lower than the previous ones. Discrepancies with the studies done in Colombia may be due to differences in the anatomical site and the reference method used (BUENDÍA et al., 2016). It can also be explained by the fact that the sample was obtained between 1995 and 2013, a period during which epidemiological changes related to overweight and obesity have occurred (RAMIREZ-VELEZ et al., 2017).

It is estimated that over the last few decades there has been an increase in the average BMI worldwide, of $0.63 \mathrm{~kg} / \mathrm{m} 2$ for men and $0.59 \mathrm{~kg} / \mathrm{m} 2$ for women. However, it should be stressed that over time they may weigh an additional $1.5 \mathrm{~kg}$ (NCD-RISC, 2016). This same transition in the prevalence of obesity has occurred in both developed and developing countries (GARCIA, 2017). A similar phenomenon has occurred in Colombia. The 2010 National Health and Nutrition Survey (ENSIN) showed that the Colombian population had increased its levels of overweight and obesity by $5.6 \%$ about the 2005 survey (FONSECA-CENTENO, 2010). Therefore, it is likely that the people evaluated in 1995 were thinner than those of the three Colombian studies already mentioned, carried out in 2013, 2015 and 2016 respectively.

The results of this study are similar to those of others that show a positive correlation between BMI and WC in both sexes (SMITH and HASLAM, 2007); although they differ from another study showing positive correlation for women but not for men (FREEDMAN and FORD, 2015). BMI and WC have good sensitivity and specificity to predict body fat percentage. However, in our study, the highest level of prediction was obtained with WCN. This result is consistent with studies showing that WC is a major predictor for indirectly determining intra-abdominal fat (CABRAL et al., 2015). These data are in line with those of other studies showing limitations of BMI, especially as BMI does not distinguish between lean body mass and fat body mass (NUTTALL, 2015; SILVA et al., 2012). Thus, it is necessary to add the estimation of total fat percentage and body distribution using WC measurement to obtain a more accurate evaluation of the body composition of each subject. 
Our study has some limitations. The fact that the sample is for convenience prevents extrapolating the results to the rest of the population. It should also be noted that other variables that could influence body composition, such as levels of physical activity, ethnicity or socioeconomic status, were not included. These factors modulate growth and levels of adiposity (19).

The present study contributes to a better knowledge of the diverse Colombian population, allowing us to understand the differences between the cut-off points of other regions of the country and even other nations. In Colombia, obesity can reach prevalence levels of $62 \%$ (RUIZ et al., 2012). It is, therefore, necessary to define new cut-off points for the waist circumference due to the epidemiological changes that occur in the populations. This should be done not only because of its effectiveness and low cost but also because it can contribute to a better approach to this public health problem by allowing to carry out early screening using affordable anthropometric instruments. Finally, suitable cut-off points are required for the Colombian and Latin American population, since there are still divergences in different studies (LIMPAWATTANA et al., 2014).

\section{Conclusions}

WCN measurement has greater sensitivity and specificity than BMI to predict body fat percentage. Cutting points for the WCN were found to be $70 \mathrm{~cm}$ for men and $64 \mathrm{~cm}$ for women. These points can be compared with other studies in Colombia and serve as a reference for college students with similar characteristics. The practical value of our study at present is to reinforce the idea that both researchers, as well as, clinicians should measure and report not only BMI but also the waist circumference and this should preferably be measured at the same parameterized level. Concerning future research, it ought to be worth working with samples that represent wider populations either at regional or even at the national level.

\section{Acknowledgments}

To Dr. Luz Helena Sepulveda, for her collaboration and advice in this research's statistics. Also, we want to thank Dr. Laura Victoria Florez Aristizabal for her contribution to the recollection and the order of the data. To the students who participate in the study. We also thank reviewers and editors for their comments.

\section{Conflict of interest}

The authors declare that they do not have any conflict of interest. 
RAMIREZ-CALDERON, B. J.; GONZALEZ-CORREA, C. L.; GONZALEZ-CORREA, C. A. Pontos de corte de circunferência de cintura ou índice de massa corporal para previsão de massa de gordura em estudantes universitários. Rev. Bras. Biom. Lavras, v.38, n.2, p.147-158, 2020.

- RESUMO: A obesidade afeta milhões de pessoas em todo o mundo, tornando-se um problema de saúde pública com sérias implicações para a qualidade de vida humana. É por isso que estratégias de prevenção e diagnóstico de baixo custo, acessiveis a toda a população, são necessárias. Estratégias de baixo custo e fáceis de usar incluem a medição do Índice de Massa Corporal (IMC) e a medida da circunferência da cintura (CC). Determinar se a porcentagem de gordura corporal em universitários pode ser prevista pelo IMC ou CC, estabelecendo pontos de corte de CC. Estudo descritivo de corte transversal com amostra aleatória simples. O estudo incluiu 687 estudantes com idades entre 18 e 35 anos de ambos os sexos. Os dados obtidos das participantes foram medidas antropométricas: peso, comprimento, circunferência da cintura em umbigo e dobras cutâneas (bicipital, tricipital, subescapular e supra-ilíaca). A sensibilidade e especificidade do IMC e da circunferência da cintura ao nível do umbigo (WCN) foram determinadas para prever a percentagem estimada de gordura corporal através da medição de dobras cutâneas. Os pontos de corte da circunferência da cintura para homens e mulheres foram determinados pela elaboração de uma Curva Receiver Operating Characteristic (ROC). Maior sensibilidade e especificidade da CC foram encontradas em relação ao IMC, para predizer a porcentagem de gordura corporal.

- PALAVRAS-CHAVE: Obesidade; índice de massa corporal (IMC); circunferência da cintura (WC); espessura das dobras cutâneas.

\section{References}

ALBERTI, K. G.; ZIMMET, P.; SHAW, J. The metabolic syndrome - a new worldwide definition. Lancet, v.366, n.9491, p.1059-62, 2005.

ALEMAN-MATEO, H.; CARREON, V. R.; MACIAS, L.; ASTIAZARAN-GARCIA, H.; GALLEGOS-AGUILAR, A. C.; ENRIQUEZ, J. R. Nutrient-rich dairy proteins improve appendicular skeletal muscle mass and physical performance and attenuate the loss of muscle strength in older men and women subjects: a single-blind randomized clinical trial. Clinical Interventions in Aging. v.9, p.1517-25, 2014.

BUENDÍA, R.; ZAMBRANO, M; DÍAZ, Á.; REINO, A.; RAMÍREZ, J.; ESPINOSA, E. Puntos de corte de perímetro de cintura para el diagnóstico de obesidad abdominal en población colombiana usando bioimpedanciometría como estándar de referencia. Revista Colombiana de Cardiologia, v.23, n.1, p.19-25, 2016.

CABRAL ROCHA, A. L.; FELICIANO PEREIRA, P.; CRISTINE PESSOA, M.; GONCALVES ALFENAS, R. D. E. C.; SEGHETO, W.; SILVA, D. C.; PACHECO ANDRADE, M.; ZARBATO LONGO, G. Hypertriglyceridemic waist phenotype and cardiometabolic alterations in brazilian adults. Nutrición Hospitalaria, v.32, n.3, p.1099$106,2015$.

DURNIN, J. V.; WOMERSLEY, J. Body fat assessed from total body density and its estimation from skinfold thickness: measurements on 481 men and women aged from 16 to 72 years, British Journal of Nutrition, v.32, n.1, p.77-97, 1974. 
FONSECA-CENTENO， Z.; HEREDIA-VARGAS， A.; OCAMPO-TÉLLEZ， R.; FORERO-TORRES, Y.; SARMIENTO-DUEÑAS, O.; ÁLVAREZ-URIBE, M. Encuesta Nacional de la Situación Nutricional en Colombia. 2010-ENSIN. Bogotá, DC: Instituto Colombiano de Bienestar Familiar. 2011.

FREEDMAN, D. S.; FORD, E. S. Are the recent secular increases in the waist circumference of adults independent of changes in BMI? American Journal of Clinical Nutrition, v.101, n.3, p.425-31, 2015.

GARCÍA, B. V. Tendencias alimentarias que han propiciado la nueva forma de desnutrición en sobrepeso y obesidad: causas, prevalencia y factores añadidos. Available at: https://www.3ciencias.com/libros/libro/tendencias-alimentarias-propiciado-la-nuevaforma-desnutricion-sobrepeso-obesidad/, 2017.

GONZÁLEZ-MUNIESA, P.; MÁRTINEZ-GONZÁLEZ, M-A.; HU, F. B.; DESPRÉS, JP.; MATSUZAWA, Y.; LOOS, R. J. F.; MORENO, L. A.; BRAY, G. A; MARTINEZ, J. A. Obesity - Nature Reviews Disease Primers, v.3, p.17034, 2017.

HERNÁNDEZ, A. G. A.; PADILLA, S. G.; ARAYA, M. R. La circunferencia abdominal como indicador de riesgo de enfermedad cardiovascular. Acta Médica Costarricense, v.55, n.3, p.122-127, 2013.

HU, H. et al. Optimal waist circumference cut-off points and ability of different metabolic syndrome criteria for predicting diabetes in Japanese men and women: Japan Epidemiology Collaboration on Occupational Health Study. BMC Public Health, v.16, p.220, 2016.

KAVAK, V.; PILMANE, M.; KAZOKA, D. Body mass index, waist circumference and waist-to-hip-ratio in the prediction of obesity in Turkish teenagers. Collegium Antropologicum, v.38, n.2, p.445-51, 2014.

KLEIN, S.; ALLISON, D. B.; HEYMSFIELD, S. B.; KELLEY, D. E.; LEIBEL, R. L.; NONAS, C.; KAHN, R. Waist circumference and cardiometabolic risk: a consensus statement from Shaping America's Health: Association for Weight Management and Obesity Prevention; NAASO, The Obesity Society; the American Society for Nutrition; and the American Diabetes Association. American Journal of Clinical Nutrition, v.85, n.5, p.1197-202, 2007.

LIMPAWATTANA, P.; KENGKIJKOSOL, T.; ASSANTACHAI, P.; KRAIRIT, O.; PIMPORM, J. The Performance of Obesity Screening Tools Among Young Thai Adults. Journal of Community Health. Biomedical Research India, v.39, n.6, p.1216-21, 2014.

LOHMAN, T.; ROACHE, A.; MARTORELL, R. Anthropometric standardization reference manual. Medicine \& Science in Sports \& Exercise, v.24, n.8, p.952, 1992.

MACIAS, N.; QUEZADA, A. D.; FLORES, M.; VALENCIA, M. E.; DENOVAGUTIERREZ, E.; QUITERIO-TRENADO, M.; GALLEGOS-CARRILLO, K.; BARQUERA, S.; SALMERON, J. Accuracy of body fat percent and adiposity indicators cut off values to detect metabolic risk factors in a sample of Mexican adults. BMC Public Health, v.14, p.341, 2014. 
NCD-RisC. NCD Risk Factor Collaboration. Trends in adult body-mass index in 200 countries from 1975 to 2014: a pooled analysis of 1698 population-based measurement studies with 19.2 million participants. Lancet, v.387, n.10026, p.1377-96, 2016.

NUTTALL, F. Q. Body Mass Index: Obesity, BMI, and Health: A Critical Review. Nutr. Today, v.50, n.3, p.117-28, 2015.

OTTAIANO, A.; DE, C. D.; CAPOZZI, M.; AVALlONE, A.; PISANO, C.; PIGNATA, S., TAFUTO, S. Obesity and cancer: biological links and treatment implications. Curr. Cancer Drug Targets, v.18, n.3, p.231-238, 2018.

RAMIREZ-VELEZ, R.; CORREA-BAUTISTA, J. E.; MARTINEZ-TORRES, J.; MENESES-ECHAVEZ, J. F.; GONZALEZ-RUIZ, K.; GONZALEZ-JIMENEZ, E.; SCHMIDT-RIOVALLE, J.; LOBELO, F. LMS tables for waist circumference and waistheight ratio in Colombian adults: analysis of nationwide data 2010. European Journal of Clinical Nutrition, v.70, n.10, p.1189-96, 2016.

RAMIREZ-VELEZ, R.; CORREA-BAUTISTA, J. E.; SANDERS-TORDECILLA, A.; OJEDA-PARDO, M. L.; COBO-MEJIA, E. A.; CASTELLANOS-VEGA, R. D. P.; GARCIA-HERMOSO, A.; GONZALEZ-JIMENEZ, E.; SCHMIDT-RIOVALLE, J.; GONZALEZ-RUIZ, K. Percentage of Body Fat and Fat Mass Index as a Screening Tool for Metabolic Syndrome Prediction in Colombian University Students. Nutrients, v.9, n.9, pii: E1009, 2017.

RAO, G.; POWELL-WILEY, T. M.; ANCHETA, I.; HAIRSTON, K.; KIRLEY, K.; LEAR, S. A.; NORTH, K. E.; PALANIAPPAN, L.; ROSAL, M. C. Identification of Obesity and Cardiovascular Risk in Ethnically and Racially Diverse Populations: A Scientific Statement from the American Heart Association. Circulation, v.132, n.5, p.45772, 2015.

RIVERA, J. A.; DE COSSIO, T. G.; PEDRAZA, L. S.; ABURTO, T. C.; SANCHEZ, T. G.; MARTORELL, R. Childhood and adolescent overweight and obesity in Latin America: a systematic review. Lancet - Diabetes and Endocrinology, v.2, n.4, p.321-32, 2014.

ROMAIN, A. J.; BERNARD, P.; ATTALIN, V.; GERNIGON, C.; NINOT, G.; AVIGNON, A. Health-related quality of life and stages of behavioral change for exercise in overweight/obese individuals. Diabetes \& Metabolism, v.38, n.4, p.352-8, 2012.

ROSS, R.; BERENTZEN, T.; BRADSHAW, A. J.; JANSSEN, I.; KAHN, H. S.; KATZMARZYK, P. T.; KUK, J. L.; SEIDELL, J. C.; SNIJDER, M. B.; SORENSEN, T. I.; DESPRES, J. P. Does the relationship between waist circumference, morbidity and mortality depend on measurement protocol for waist circumference? Obesity Reviews, v.9, n.4, p.312-25, 2008.

RUIZ, Á. J; ASCHNER, P. J.; PUERTA, M. F.; ALFONSO-CRISTANCHO, R. Estudio IDEA (International Day for Evaluation of Abdominal Obesity): prevalencia de obesidad abdominal y factores de riesgo asociados en atención primaria en Colombia. Biomédica, v.32, n.4, p.603, 2012. 
SHARIATPANAHI, R. S.; VAHDAT, Z. Comparison of Waist Circumference Measured at Four Sites in Healthy Iranian Adults. Malaysian Journal of Nutrition, v.22, n.2, p.6, 2016.

SILVA, D. A. S.; PETROSKI, E. L.; PERES, M. A. Is high body fat estimated by body mass index and waist circumference a predictor of hypertension in adults? A populationbased study. Nutritional Journal, v.11, p.112, 2012.

SMITH, S. C.; HASLAM, D. Abdominal obesity, waist circumference and cardiometabolic risk: awareness among primary care physicians, the general population and patients at risk--the Shape of the Nations survey. patients at risk--the Shape of the Nations survey. Current Medical Research and Opinion, v.23, n.1, p.29-47, 2007.

STANLEY, T. L.; GRINSPOON, S. K. Effects of growth hormone-releasing hormone on visceral fat, metabolic, and cardiovascular indices in human studies. Growth Hormone \& IGF Research, v.25, n.2, p.59-65, 2015.

WALL-MEDRANO, A.; RAMOS-JIMÉNEZ, A.; HERNANDEZ-TORRES, R. P.; VILLALOBOS-MOLINA, R.; TAPIA-PANCARDO, D. C.; JIMÉNEZ-FLORES, J. R.; MÉNDEZ-CRUZ, A. R.; MURGUÍA-ROMERO, M.; GALLARDO-ORTÍZ, I. A.; URQUÍDEZ-ROMERO, R. Cardiometabolic risk in young adults from northern Mexico: Revisiting body mass index and waist-circumference as predictors. BMC Public Health, v.16, p.236, 2016.

YANG, F. et al. Receiver-operating characteristic analyses of body mass index, waist circumference and waist-to-hip ratio for obesity: Screening in young adults in central south of China. Clinical Nutrition, v.25, n.6, p.1030-9, 2006.

Received on 24.05.2019

Approved after revised on 28.11.2019 